\title{
A phylogenetic analysis of Antrodia s.l. based on nrDNA ITS sequences, with emphasis on rhizomorphic European species
}

\author{
Annarosa Bernicchia • Sergio Pérez Gorjón • \\ Petr Vampola $\cdot$ Leif Ryvarden • Antonio Prodi
}

Received: 25 August 2010 /Revised: 28 November 2010 / Accepted: 3 December 2010 /Published online: 24 December 2010

(C) The Author(s) 2010. This article is published with open access at Springerlink.com

\begin{abstract}
The rhizomorphic European species of Antrodia, belonging to the traditionally called Antrodia radiculosa group, are investigated. On the basis of morphological and molecular analysis, the genus Fibroporia is supported. Specimens from Central Europe previously ascribed to Antrodia radiculosa constitute a species of their own, and are herein described as Fibroporia bohemica. Moreover, a new combination, Fibroporia citrina, is proposed.
\end{abstract}

Keywords Antrodia Fibroporia - Wood-inhabiting fungi . Polypores $\cdot$ ITS $\cdot$ Molecular phylogeny

\footnotetext{
A. Bernicchia $\cdot$ A. Prodi

Dipartimento di Scienze e Tecnologie Agroambientali,

Università degli Studi di Bologna,

Via Fanin 42,

40127 Bologna, Italy

A. Bernicchia

e-mail: annarosa.bernicchia@unibo.it

A. Prodi

e-mail: antonio.prodi@unibo.it

S. P. Gorjón $(\bowtie)$

Departamento de Botánica, Universidad de Salamanca,

Avda. Licenciado Méndez s/n,

37007 Salamanca, Spain

e-mail: spgorjon@usal.es

P. Vampola

Smrčna 109 ,

58801 Smrčna u Jihlavy, Czech Republic

e-mail: vampolapetr@volny.cz

L. Ryvarden

Botanical Institute, University of Oslo,

P.O. Box 1066, Blindern,

0316 Oslo, Norway

e-mail: leif.ryvarden@bio.uio.no
}

\section{Introduction}

The genus Antrodia P. Karst. in a wide sense includes species with a dimitic hyphal system, clamped generative hyphae and causing a brown rot (Ryvarden 1991; Ryvarden and Gilbertson 1993). The genus thus defined is heterogeneous, and it has long been regarded as a polyphyletic group due to variations in macro- and micromorphological characters such as the structure of basidiomata, basidiospores morphology, an iodine reaction of hyphae and sexuality (Lombard 1990; Ryvarden 1991; Ryvarden and Gilbertson 1993; Kim et al. 2001). About 50 species have been described (Kirk et al. 2001; Dai and Niemelä 2002), of which around 30 are known to be present in Europe.

Among the polyporoid fungi, Antrodiella Ryvarden \& I. Johans. and Diplomitoporus Domanski have been traditionally regarded as the closely related genera to Antrodia, sharing similar basidiomata and dimitic hyphal system with clamped generative hyphae, but differing in the type of rot, brown in Antrodia and white rot in Antrodiella and Diplomitoporus. Wood rot type seems to be of phylogenetic importance and Antrodia has been shown more closely related to other genera with brown rot such as Fomitopsis P. Karst., Daedalea Pers., Gloeophyllum P. Karst., and Oligoporus Bref. than to other polypores with white rot such as Antrodiella, Diplomitoporus, Junghuhnia Corda, and Ceriporiopsis Domanski (Kim et al. 2003).

Parmasto (1968) described the genus Fibroporia to accommodate species with fimbriate to rhizomorphic margin and ellipsoid basidiospores with Polyporus vaillantii DC. as the generic type species, proposing the following combinations: Fibroporia vaillantii (DC.) Parmasto, F. gossypium (Speg.) Parmasto, F. destructor (Fr.) Parmasto, F. radiculosa (Peck) Parmasto, and F. overholtsii (Pilát.) Parmasto. Ryvarden (1991) regards the rhizomorphs as an adaptive 
character not enough to justify a generic separation and synonymised Fibroporia to Antrodia. Molecular studies by Kim et al. (2001), however, support the monophyletic group of $F$. vaillantii and $F$. gossypium. In addition, Fibroporia is distinguished from Antrodia by the generative hyphae that do not possess irregularly thickened walls, distinct to slightly thick-walled basidiospores, and tetrapolar sexuality (usually homothallic or heterothallic bipolar in Antrodia) (Rajchenberg 2006).

Neolentiporus Rajchenb. is phylogenetically closely related to Antrodia s.str. as was recently showed by nuc-LSU rDNA sequence data (Yu et al. 2010). Amyloporia Bondartsev \& Singer is separated from Antrodia s.str. by the skeletal hyphae that either are amyloid or swell in $\mathrm{KOH}$ solution, and by the heterocytic nuclear behaviour (normal in Antrodia). The phylogenetic relationships of Amyloporia are still not fully resolved (Yu et al. 2010).

In the present study, rhizomorphic Antrodia species (Antrodia radiculosa complex) from Europe have been morphologically and phylogenetically analyzed and compared with American and East Asian specimens of Antrodia radiculosa as well with other non-rhizomorphic Antrodia species.

\section{Material and methods}

Macro- and microscopic examinations

Specimens were studied in Melzer's reagent (IKI) and $\mathrm{KOH}$ (3\%) under a Leitz Dialux 22 EB microscope. Measurements (where basidiospores apiculus is excluded) and drawings were made in $\mathrm{KOH}(3 \%)$ reagent.

Phylogenetic analysis

Genomic DNA of strains was extracted from basidiomata of the different analyzed species. The extraction method of Lohdi et al. (1994) with CTAB was adapted. Primers ITS4 and ITS5 (White et al. 1990) were used to amplify part of the nuclear ribosomal DNA (rDNA). PCR was carried out in a final volume of $25 \mu \mathrm{l}$ containing: $5 \mu \mathrm{l}$ of diluted sample, 0.75 units of GoTaq Flexi DNA polymerase (Promega, Madison, Wi, USA), 5X Green GoTaq Flexi Buffer, $0.2 \mathrm{mM}$ dNTP, $3 \mathrm{mM} \mathrm{MgCl}_{2}$ (Promega) and 2.5 pmol of each primer.

Amplifications were performed in a thermal cycler (T3 Thermocycler, Biometra) using an initial denaturation step of $94^{\circ} \mathrm{C}$ for $5 \mathrm{~min}$, followed by 30 cycles of denaturation at $94^{\circ} \mathrm{C}$ for $1 \mathrm{~min}$, annealing for $1 \mathrm{~min}$ at $56^{\circ} \mathrm{C}$ and elongation for $1 \mathrm{~min}$ at $72^{\circ} \mathrm{C}$. This was concluded with a final extension for $10 \mathrm{~min}$ at $72^{\circ} \mathrm{C}$. PCR products were analyzed by electrophoresis in 1\% agarose gel in TBE $1 \mathrm{X}$ (54 g Tris
Base, $27.5 \mathrm{~g}$ boric acid, $20 \mathrm{ml}$ EDTA pH 8.0), stained with ethidium bromide $(0.4 \mu \mathrm{g} \mathrm{ml}-1)$ and photographed under UV. The molecular weight of the amplified DNA was estimated by comparison with a "100 bp DNA ladder" (Promega).

The amplified products were purified (Wizard SV Gel and PCR Clean-Up System, Promega) and ligated into the pGEM-T easy vector (Promega), which was then used to transform competent cells of JM109 Escherichia coli (Promega), and recombinant plasmid DNA from transformed cells was purified (Wizard Plus SV Minipreps DNA Purification System, Promega). Colonies containing the insert were screened by PCR with primers designed on the polylinker of the vector. Sequencing work was done by a commercial company (MWG - Germany).

Sequences were aligned using the multiple-sequence alignment program Clustal W (Higgins and Sharp 1989) from the Megalign package (DNAStar, USA). Phylogenetic analysis were performed by the maximum parsimony method using the heuristic search algorithm of PAUP* program version 4.0b10 (Swofford 1998), and the neighbor-joining method of MEGA 4 (Tamura et al. 2007). Maximum parsimony trees were obtained with heuristic research with 1000 random taxa stepwise addition sequences, tree-bisection-reconnection (TBR) branch swapping algorithm was performed. Robustness of clades was assessed by the bootstrap method using 1000 heuristic search replicate. Trees were edited in MEGA 4 (Tamura et al. 2007). The sequences of Antrodia juniperina (AY 966454), Antrodia malicola (AY 966449), Antrodia sinuosa (AY 966450), Antrodia sitchensis (AY 966451), Antrodia variiformis (AY 966453), Antrodiella semisupina (AF126905), Auricularia auricula-judae (EU520237), Daedalea quercina (FJ403214), Diplomitoporus flavescens (FN907908), Exidia recisa (AF291276), Fibroporia radiculosa (FJ644284), Fibroporia vaillantii (AM286436, AJ421008), Fomitopsis pinicola (EF530947), Gloeophyllum abietinum (GQ354271), Gloeophyllum sepiarium (AY089732), Laetiporus sulphureus (AY089742), Oligoporus lacteus (FJ627254), and Piptoporus betulinus (EU661888) are from the National Centre for Biotechnology Information (NCBI) GenBank. New sequences of Antrodia sinuosa (GU991578), Fibroporia bohemica (GU991575, GU991577, HM590887, HM590888, HM590889, HM590890), Fibroporia citrina (GU991573, HM542005, HM542006), Fibroporia gossypium (GU991576, HM590880, HM590881), Fibroporia radiculosa (GU991574, HM590882, HM590883), Fibroporia vaillantii (HM590884, HM590885, HM590886), Poria saxonica (GU991572) were deposited in GenBank (see Table 1). Auricularia auricula-judae, Exidia recisa, Piptoporus betulinus, and Oligoporus lacteus were used as outgroups. 
Table 1 Specimens included in this study. In bold the new accession Genbank number referred to the sequences obtained from this study

\begin{tabular}{|c|c|c|c|}
\hline Species & Collector number or strain & Locality & GenBank accession $n^{\circ}$ \\
\hline Antrodia juniperina & H.S. Wu \& Y.S. Yu, strain FP97452T & $?$ & AY966454 \\
\hline Antrodia malicola & H.S. Wu \& Y.S. Yu, strain MJL1167SP & $?$ & AY966449 \\
\hline Antrodia sinuosa & H.S. Wu \& Y.S. Yu, strain RLG1182R & $?$ & AY966450 \\
\hline Antrodia sinuosa & HUBO 8400 & Italy, Sardinia & GU991578 \\
\hline Antrodia sitchensis & H.S. Wu \& Y.S. Yu, strain HHB12513 & China & AY966451 \\
\hline Antrodia variiformis & H.S. Wu \& Y.S. Yu, strain FP90100SP & $?$ & AY966453 \\
\hline Antrodiella semisupina & Coll. P. Renvall 3497 (KUO) & Finland, Lammi & AF126905 \\
\hline Auricularia auricula-judae & Coll. Z. Yu, isolate NW484 & China ? & EU520237 \\
\hline Daedalea quercina & Coll H.H. Burdsall, Jr. 8735 & U.S.A. & FJ403214 \\
\hline Diplomitoporus flavescens & H. Gunter s.n. lab no O. Miettinen X84 & Germany & FN907908 \\
\hline Exidia recisa & M. Weiss 315 & Germany & AF291276 \\
\hline Fibroporia bohemica & Coll. P. Vampola 12/12/2000 & Czech Republic, Bohemia & HM590888 \\
\hline Fibroporia bohemica & Coll. P. Vampola 06/09/2002 & Czech Republic, Bohemia & HM590887 \\
\hline Fibroporia bohemica & Coll. P. Vampola 3/04 & Czech Republic, Bohemia & HM590889 \\
\hline Fibroporia bohemica & Coll. P. Vampola 327/91, HUBO 8479 & Czech Republic, Bohemia & GU991575 \\
\hline Fibroporia bohemica & BRNM 612444, HUBO 8480 & Italy, Trentino Alto-Adige & GU991577 \\
\hline Fibroporia bohemica & PRM 859138, holotypus & Czech Republic, Bohemia & HM590890 \\
\hline Fibroporia citrina & Coll. HUBO G. Trichies 7237 & France & HM542006 \\
\hline Fibroporia citrina & HUBO 7887 & Italy, Emilia-Romagna & HM542005 \\
\hline Fibroporia citrina & HUBO 7715 & Italy, Emilia-Romagna & GU991573 \\
\hline Fibroporia gossypium & HUBO 7724 & Italy, Sardinia & HM590880 \\
\hline Fibroporia gossypium & HUBO 7952 & Italy, Veneto & HM590881 \\
\hline Fibroporia gossypium & HUBO 7725 & Italy, Sardinia & GU991576 \\
\hline Fibroporia radiculosa & Coll. HUBO Y.C. Dai 3577 & China & HM590883 \\
\hline Fibroporia radiculosa & Coll. B.K. Cui 2797 & China & FJ644284 \\
\hline Fibroporia radiculosa & Coll. HUBO Y.C. Dai 6473 & China & HM590882 \\
\hline Fibroporia radiculosa & Coll. Rogers 89668, HUBO 8478 & U.S.A. & GU991574 \\
\hline Fibroporia vaillantii & HUBO 8160 & Italy, Sardinia & HM590885 \\
\hline Fibroporia vaillantii & HUBO 8158 & Italy, Sardinia & HM590886 \\
\hline Fibroporia vaillantii & Coll. K. Grimm 1991 & Germany, Karlsruhe & AJ421008 \\
\hline Fibroporia vaillantii & O. Schmidt \& U. Moreth, isolate 240 & Germany, Karlsruhe & AM286436 \\
\hline Fibroporia vaillantii & Herb. H. Ostrow 2120 & Germany, Bavaria & HM590884 \\
\hline Fomitopsis pinicola & Coll. S. Brar. UBC F16252 & Canada & EF530947 \\
\hline Gloeophyllum abietinum & Baars et al., strain DSM 1210 & $?$ & GQ354271 \\
\hline Gloeophyllum sepiarium & Isolate Fp-105551-sp & $?$ & AY089732 \\
\hline Laetiporus sulphureus & S.H. Kim et al. Da-11(Tb) & $?$ & AY089742 \\
\hline Oligoporus lacteus & Coll. B.K. Cui 5724 & China & FJ627254 \\
\hline Piptoporus betulinus & D. Cui, M. Zhao \& H. Yang, strain 009 & China & EU661888 \\
\hline Poria saxonica & HUBO 8481, MTB 5434, typus & Germany, Bavaria & GU991572 \\
\hline
\end{tabular}

\section{Results}

Morphological analysis

All the species under observation: Fibroporia radiculosa from the United States (coll. Rogers 89668) and China (coll. YC 3577, YC6473), Poria saxonica (coll. typus MTB
5434, Herb. H. Ostrow 2120), "Fibroporia radiculosa" from Czech Republic (Bohemia) (coll. Vampola: 336/92, 327/91, 3/04, VI/09/2002, 12/VIII/2000), "Fibroporia radiculosa" from Italy (coll. BRNM 612444), Fibroporia vaillantii (coll. HUBO 8158, 8160, MTB 5434), Fibroporia gossypium (coll. HUBO 7952, 7724, 7725), Antrodia citrina (coll. HUBO 7715, 7887) and a close related 
specimen of Antrodia (cf. citrina) from France (coll. G. Trichies 7237).

Fibroporia radiculosa from the United States and China and "Fibroporia radiculosa" from Europe belong to the Fibroporia radiculosa group, presenting a yellow colour of the hymenophore. Antrodia citrina and Antrodia sp. (cf. citrina) from France have a cream to pale yellow colour of fertile surface, while $F$. vaillantii and $F$. gossypium have a whitish colour.

Antrodia citrina shows a cream to pale yellow or lemon olivaceous basidiomata with conspicuous bright yellow rhizomorphs. Basidiospores are broadly ellipsoid to subglobose 4-5 × 3-3.5(3.8) $\mu \mathrm{m}$ (Fig. 1b), differing clearly both from the larger ellipsoid basidiospores of Fibroporia radiculosa from North America and those of the Central European taxon. For a complete description see Bernicchia (2005).

Fibroporia radiculosa shows a yellowish to bright orange pore surface with yellowish rhizomorphs. It has been impossible to keep a look of the type of $F$. radiculosa, because the specimen was a mass of powdery material. Basidiospores in F. radiculosa from North America are broadly ellipsoid, measuring 6-8 × 3-4 $\mu \mathrm{m}$ (Fig. 1c). As stated by Ryvarden and Gilbertson (1993), specimens of Poria saxonica Dörfelt are morphological similar to $F$. radiculosa, and this type of species, showing a cream orange colour of the pore surface (probably darkened by age), differs neither macroscopically nor microscopically from F. radiculosa from North America, showing similar bur shorter basidiospores (Fig. 1d).

Specimens from Czech Republic and Italy, previously identified as Fibroporia radiculosa (Vampola 1992) or Antrodia radiculosa (Ryvarden and Gilbertson 1993; Bernicchia 2005), differ from American specimens of $F$. radiculosa in having smaller basidiospores: (4.8-)5-5.5 $\times$ (2.6-)2.8-3(-3.2) $\mu \mathrm{m}$ of an ellipsoid to subcylindrical shape.

Phylogenetic analysis

The complete alignment of the ITS region was $679 \mathrm{bp}$ long, but 30 extreme 5' positions and 59 extreme 3' positions were excluded from all analyses, because they were incomplete for some taxa. The final alignment was 590 including 215 constant characters, 68 parsimonyuninformative variable characters and 307 parsimonyinformative characters.

Analyses of the nrDNA ITS dataset were grouped into two main groups: "Fibroporia" group and "Antrodia" group (Fig. 2). The Fibroporia group comprises a wellsupported group with a $95 \%$ ( $100 \%$ in NJ, data not shown) bootstrap support value and includes $F$. gossypium, $F$. bohemica, F. radiculosa, Antrodia citrina, and Poria saxonica, as well as the generic type species, $F$. vaillantii.
The new species reported here appeared in the wellsupported Fibroporia clade and differed from other Fibroporia species. Antrodia citrina is phylogenetically recovered among the Fibroporia group.

The Antrodia group comprises a series of species belonging to genus Antrodia: A. juniperina, A. malicola, A. sinuosa, A. sitchensis, A. variiformis, as well as Daedalea and Fomitopsis. Wu et al. (2004) also recovered Fomitopsis pinicola in the Antrodia group.

\section{Discussion}

Fibroporia vaillantii, the type of species of Fibroporia, forms with the other rhizomorphic species a well differentiated and supported clade, named Fibroporia group, separated from that of Antrodia s.str. species (Fig. 2), which confirms the generic delimitation proposed by Parmasto (1968) and suggested also by other molecular studies (Kim et al. 2001).

The type of Poria saxonica, identified as Antrodia radiculosa by Ryvarden and Gilbertson (1993), and included in the present molecular study, clusters with other specimens of Fibroporia vaillantii, and therefore, we can regard $P$. saxonica as a heterotypic synonym of $F$. vaillantii. Some rhizomorphic specimens of Fibroporia (HUBO 8160 Sardinia, Italy; Ostrow 2120 - Bavaria, Germany) clustered also with specimens of $F$. vaillantii.

Antrodia citrina Bernicchia \& Ryvarden, was recently described as a new species from Italy (Bernicchia 2005), with the following latin diagnosis: "Antrodia radiculosa (Peck) Gilbn. \& Ryvarden affinis, sed sporis ellipsoideis, 4-5 × 3.23.5(3.8) $\mu \mathrm{m}$ ". Antrodia citrina, with cream to yellowish lemon basidiomata and bright yellow rhizomorphs, belongs in the complex of yellowish rhizomorphic species, and it is separated from $F$. radiculosa both in basidiospore and pore size. Based on the results suggested by the present molecular study, we propose the following combination: Fibroporia citrina (Bernicchia \& Ryvarden) Bernicchia \& Ryvarden comb. nov. Mycobank MB 516775 -basionym: Antrodia citrina Bernicchia \& Ryvarden, Polyporaceae s.l. Fungi Europaei 10: 98, 2005. A specimen collected from France (G. Trichies 7237), very similar morphologically to Antrodia citrina, is confirmed by molecular data to belong to the same species, even if we could appreciate some small differences accepted as an intraspecific variability. Therefore, the distribution of Antrodia citrina, up until recently limited to Italy, has now expanded to France.

Fibroporia radiculosa was described as being from the United States, and it is a widely distributed species in North America (Gilbertson and Ryvarden 1986). Vampola (1992) and Ryvarden and Gilbertson (1993) synonymised with $F$. radiculosa some specimens from Central Europe with 

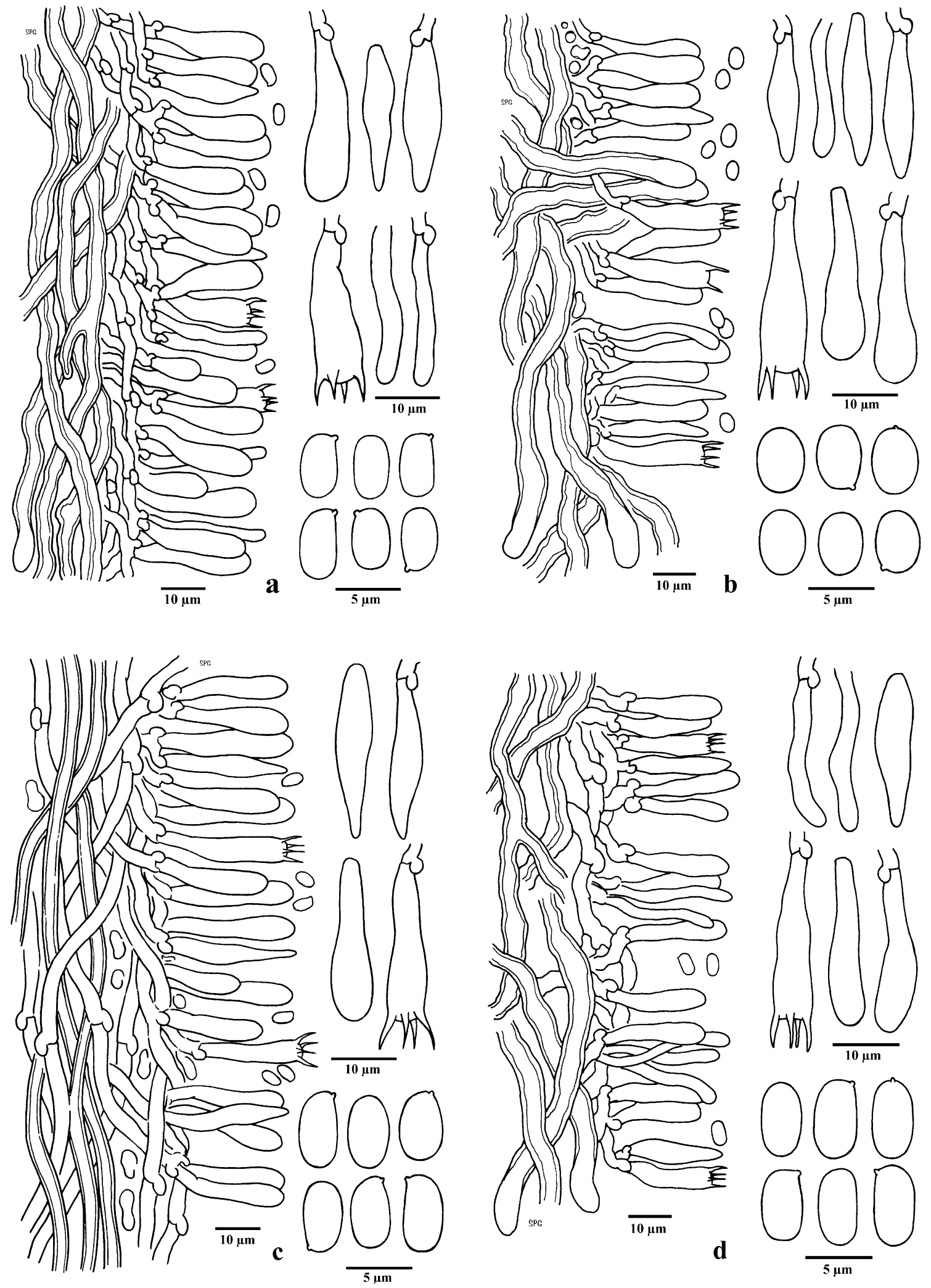

Fig. 1 Hymenial elements showing dimitic hyphal system, basidia, cystidiols and basidiospores. a Fibroporia bohemica sp. nov., coll. HUBO 7723. b Fibroporia citrina, coll. HUBO 7887. c Fibroporia

radiculosa, coll. HUBO 8478. d type of Poria saxonica $(=F$. vaillantii), coll. HUBO 8481 
Fig. 2 Maximum parsimony tree (tree length $=1324, \mathrm{CI}=$ $0,5325, \mathrm{RI}=0,7242)$ conducted in PAUP* based on aligned internal transcribed spacer (ITS) sequences and 5.8S rRNA sequences. Bootstrap percentages higher than $65 \%$ based on 1,000 replications are shown next to the branches. The bar indicates the number of expected substitutions per position. In brackets: (CHI) China; (CZE) Czech Republic; (FRA) France; (GER) Germany; (ITA) Italy; (USA) United States of America

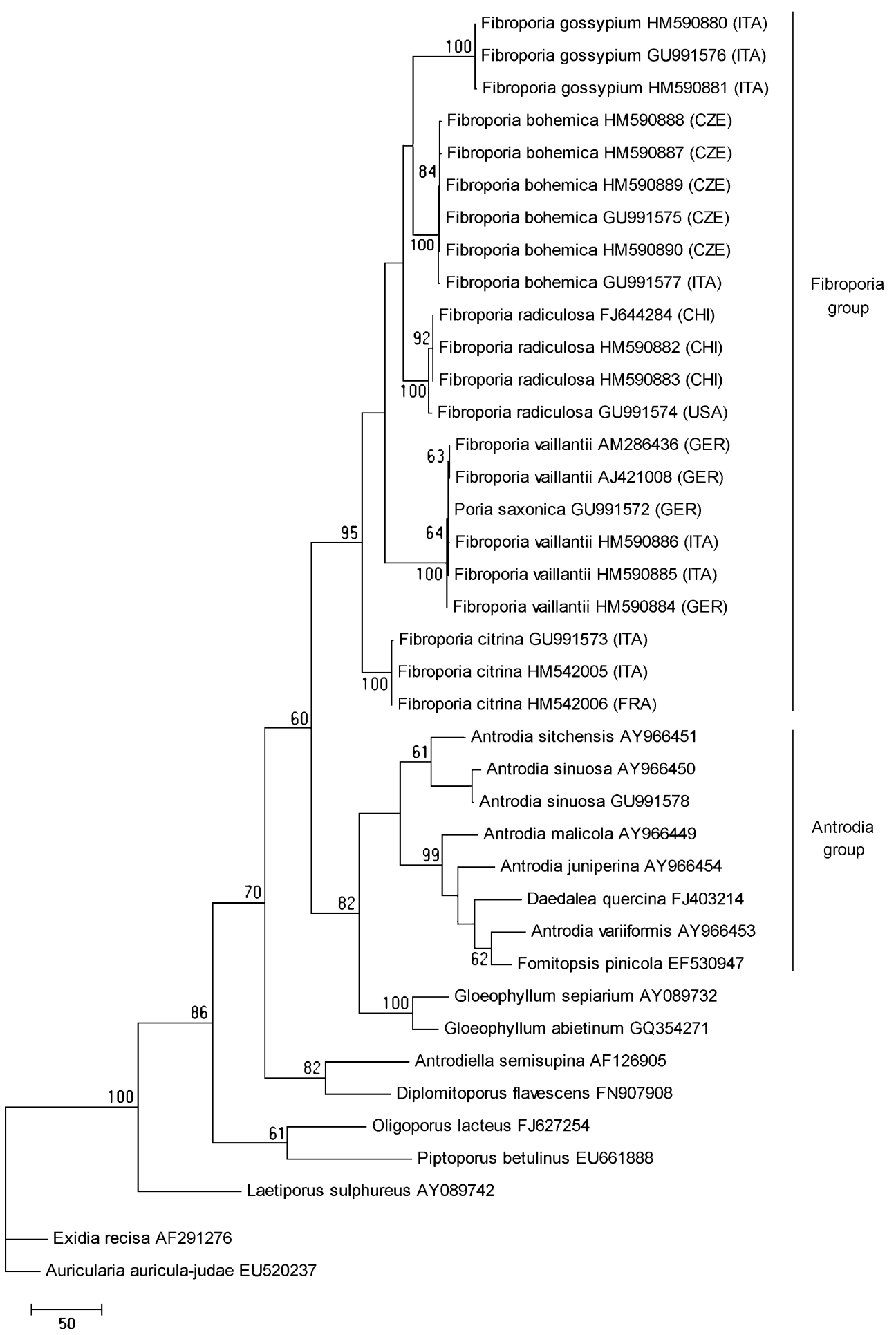

similar basidiomata and somewhat similar basidiospores. Effectively, macroscopical characters of European specimens are almost coincident. They differ from $F$. radiculosa mainly in microscopical characters because of shorter and ellipsoid to subcylindrical basidiospores (broadly ellipsoid and wider in North American specimens, 6-8 × 3-4 $\mu \mathrm{m}$ ), which was initially taken as an intraspecific variability. The results of the molecular analysis show that specimens from
Central Europe (Czech Republic and Italy) form a welldifferentiated and supported clade, different from that of the North American and East Asiatic specimens of $F$. radiculosa. It seems obvious that European specimens, previously ascribed to $F$. radiculosa, constitute a species of its own; despite the fact that they are macro- and microscopically closely related, we propose it as a new species as follows: 
Fibroporia bohemica Bernicchia, Vampola \& Prodi sp. nov.

Mycobank MB 516774

Basidiomata annua, resupinata, effusa, membranacea et a substrato separabilis, subalba deinde flava. Subiculum album et tubuli flavi. Pori rotundi vel rotundi-angulati, 2-4 per mm, dissepimentis fimbriatis. Systema hypharum dimiticum: hyphae generativae hyalinae, ramosae, fibulatae, tenuitunicatae, 2$4.5 \mu \mathrm{m}$ latae. Hyphae skeletales 3-6 $\mathrm{m}$ latae, crassitunicatae, solidae, flexuosae, rariter ramosae, leviter amyloideae. Cystidia desunt. Cystidiola hyalina, cylindrata vel hyphoidea, $20 \times 2.5-3 \mu \mathrm{m}$. Basidia clavata, hyalina, 4-sterigmatibus, 17-27(30) $\times$ 6-7.5 $\mu \mathrm{m}$. Basidiosporae hyalinae, leves, subcylindratae vel ellipsoideae, (4.8-)5-5.5 $\mathrm{\mu m}$ longae et (2.6-)2.8-3(-3.2) $\mu \mathrm{m}$ latae, inamyloideae, indextrinoideae, acyanophileae. Ad lignum arborum coniferarum.

Etymology: bohemica, from Bohemia, the western part of the Czech Republic.

Holotypus: Czech Republic, Bohemia-Moravian Uplands, Zbilidy (distr. Jihlava), the forest "Pansky les", $13 \mathrm{Km}$ WNW of Jihlava, s.m. $650 \mathrm{~m}$, Picea abies - on stump, 27.VIII.2008, leg. et det. P. Vampola (n.29/08), PRM 859138. Isotypus: HUBO 7723.

Habitat: in coniferous forests, on stumps of Picea abies, rarely of Pinus sylvestris.

Basidiomata annual, non-layered and resupinate, irregularly growing, later quite large, pelliculose, separable, covering up to tens of $\mathrm{cm}^{2}$ the surface of the substrate, at first smooth and whitish to slightly pinkish, sometimes sulphur-yellow on vertical surface. The tubes are built only later, thick-walled when fresh, sulphur-yellow (similar to those of Laetiporus sulphureus (Bull.) Murrill), contrasting with white subiculum on a cross-section, up to $6 \mathrm{~mm}$ long, sometimes cascaded. Edges of the tubes finely fimbriate, creating apex-like protrusions on the dissepiments. Pores round to round-angular, 2-4 per $\mathrm{mm}$. Rhizomorphs numerous, cream-coloured, 0.5-2(5) $\mathrm{mm}$ thick, penetrating deep into the substrate, representing a remarkable character. They are most abundant in fully developed fruitbodies growing on very decayed wood; in young fruitbodies, or on less decayed wood they are almost unnoticeable. Taste mild to slightly acid when fresh, odour strong and unpleasant, reminding one of a mixture of Fomitopsis pinicola (Sw.) P. Karst. and Gelatoporia pannocincta (Romell) Niemelä.

Hyphal system dimitic: generative hyphae thin-walled, richly branched, with clamps at septa, 2-4.5 $\mu \mathrm{m}$ in diameter. Skeletal hyphae 3-6 $\mu \mathrm{m}$ in diameter, thick- walled, unbranched or with only few branches. Hyphal walls negative or very slightly amyloid in Melzer's reagent, while are swelling inside using $\mathrm{KOH}$ solution, filling up the whole volume of the hypha. Cystidia absent. Cystidiols among the basidia numerous, hyphoid, cylindrical with obtuse apex, about $20 \times 2.5-3 \mu \mathrm{m}$. Basidia clavate, 4sterigmate, sometimes slightly constricted in the upper part, basally clamped, 17-27(-30) × 6-7.5 $\mu \mathrm{m}$. Basidiospores hyaline, smooth, ellipsoid to subcylindrical, (4.8-)5-5.5 $\times$ (2.6-)2.8-3(-3.2) $\mu \mathrm{m}$, inamyloid, indextrinoid, acyanophilous. (Fig. 1a).

Additional specimens examined: as "Antrodia radiculosa”, Czech Republic, Bohemia, Zbilidy, 16. August 1991, on Picea abies, P. Vampola 6558 (O), and from the same locality and substratum: coll. P. Vampola 336/92, 327/91, 3/04, 6/09/2002, 12/12/2000, coll. BRNM 612444 from Italy.

Acknowledgements The authors would like to thank Dr. Stefano Tonti (University of Bologna, Italy) for technical assistance and phylogenetic analysis. We are also greatly indebted to Dr. Josef Vlasák (Biology Centre of the Academy of Sciences of the Czech Republic), for his help in the DNA extraction of the type of F. bohemica and for useful comments on the manuscript. We thank an anonymous reviewer for comments on the proof.

Open Access This article is distributed under the terms of the Creative Commons Attribution Noncommercial License which permits any noncommercial use, distribution, and reproduction in any medium, provided the original author(s) and source are credited.

\section{References}

Bernicchia A (2005) Polyporacae s.l. Fungi Europei 10 (ed). Candusso, Italy

Dai YC, Niemelä T (2002) Changbai wood-rotting fungi 13. Antrodia sensu lato. Ann Bot Fenn 39:257-265

Gilbertson RL, Ryvarden L (1986) North American polypores, vol. 1: Abortiporus - Lindtneria. Fungiflora, Oslo, p 433

Higgins DG, Sharp PM (1989) Fast and sensitive multiple sequence alignments on a microcomputer. Comput Appl Biosci 5:151-153

Kim SY, Park SY, Jung HS (2001) Phylogenetic classification of Antrodia and related genera based on ribosomal RNA Internal Transcribed Spaces sequences. J Microbiol Biotechnol 11 (3):475-481

Kim SY, Park SY, Ko KS, Jung HS (2003) Phylogenetic analysis of Antrodia and related taxa based on partial mitochondrial SSU rDNA sequences. Antonie Leeuwenhoek 83:81-88

Kirk PM, Cannon PF, David JC, Stalpers JA (2001) Ainsworth \& Bisby's dictionary of the fungi, 9th edn. CAB International, Oxon

Lohdi MA, Ye G, Weeden F, Reisch BI (1994) A simple and efficient method for DNA extraction from grapevine cultivars and Vitis species. Plant Mol Biol Report 12:6-13

Lombard FF (1990) A cultural study of several species of Antrodia (Polyporaceae, Aphyllophorales). Mycologia 82:185-191

Parmasto E (1968) Conspectus systematis Corticiacearum. Inst. Zool. Bot., Tartu, p 260 
Rajchenberg M (2006) Polypores (Basidiomycetes) from the Patagonian Andes forest of Argentina. Bibliotheca Mycologica, Band 201. J. Cramer, Berlin-Stuttgart

Ryvarden L (1991) Genera of polypores. Nomenclature and taxonomy. Synopsis Fungorum 5. Fungiflora, Oslo, p 363

Ryvarden L, Gilbertson RL (1993) European polypores. Vol 1: Abortiporus - Lindtneria. Synopsis Fungorum 6. Fungiflora, Oslo, p 387

Swofford D (1998) PAUP*4.0: phylogenetic analysis using parsimony. Sinuaer Associates, Sunderland

Tamura K, Dudley J, Nei M, Kumar S (2007) MEGA4: Molecular Evolutionary Genetics Analysis (MEGA) software version 4.0. Mol Biol Evol 24:1596-1599
Vampola P (1992) The North American polypore Fibroporia radiculosa was found in Czechoslovakia. Čes Mykol 46(3-4):223-227

White TJ, Bruns T, Lee S, Taylor J (1990) Amplification and direct sequencing of fungal ribosomal RNA genes for phylogenetics. In: Innis MA, Gelfand DH, Shinsky JJ, White TJ (eds) PCR Protocols: a guide to methods and applications. Academic Press, San Diego, pp 315-322

Wu SH, Yu ZH, Dai YC, Chen CT, Su CH, Chen LC, Hsu WC, Hwang GY (2004) Taiwanofungus, a polypore new genus. Fungal Sci 19(3-4):109-116

Yu ZH, Wu SH, Wang DM, Chen CT (2010) Phylogenetic relationships of Antrodia species and related taxa based on analyses of nuclear large subunit ribosomal DNA sequences. Bot Stud 51:53-60 